\title{
Luftgekühlte Wagenmotoren
}

von

\author{
Dr.-Ing. Alfred Haesner
}

Sonderabdruck aus dem Automobiltechnischen Handbuch

16. Auflage

Herausgegeben von Ing. Richard Bussien

Technischer Verlag Herbert Cram . Berlin W 35 
